\title{
Hubungan Status Gizi dan Gangguan Tidur pada Anak Sekolah Dasar di Kecamatan Tikala Manado
}

\author{
${ }^{1}$ Inrike Y. S. Simarmata \\ ${ }^{2}$ Max F. J. Mantik \\ ${ }^{2}$ Novie H. Rampengan
}

\author{
${ }^{1}$ Program Studi Pendidikan Dokter Fakultas Kedokteran Universitas Sam Ratulangi Manado \\ ${ }^{2}$ Bagian Ilmu Kesehatan Anak Universitas Sam Ratulangi Manado \\ Email: sandovasimarmata1@gmail.com
}

\begin{abstract}
Undernutrition problem is still widespread in developing countries, including Indonesia. On the other hand, overnutrition which is the nutritional problem in developed country, is beginning to flourish in the developing countries. The nutrinitonal imbalances might be caused by inappropriate amount of sleep due to inhibition of appetite regulation and changes in hormone production. Some of the nutrients that affect sleep pattern are macronutrients and micronutrients such as vitamin B, calcium, magnesium, and iron. This study was aimed to find out the correlation between nutritional status and sleep disorder. This was an observational analytical survey study with a cross sectional design. This study was conducted at elementary schools at Tikala, Manado using purposive sampling method. Weight and height of the respondents were measured to obtain the nutritional status. Parents were asked to fill the SDSC questionnaire to obtain the sleep disorder status. Of 249 (100\%) respondents, 1 respondent $(0.4 \%)$ categorized as malnutrition; 44 respondents $(17,7 \%)$ categorized as undernutrition; 129 respondents $(52.8 \%)$ categorized as normal; 34 respondents $(13.7 \%)$ categorized as overweight; and 41 respondents $(16.5 \%)$ categorized as obese. There were 156 respondents $(62.7 \%)$ had sleep disorder meanwhile 93 respondents $(37.3 \%)$ had no sleep disorder. The Pearson correlation test showed no significant correlation between nutritional status and sleep disorder $(P>0,05)$. Conclusion: There was no signicant correlation between nutritional status and sleep disorder.
\end{abstract}

Keywords: sleep disturbance, SDSC questionnaire, nutritional status

\begin{abstract}
Abstrak: Masalah gizi kurang masih tersebar luas di negara-negara berkembang, termasuk di Indonesia namun masalah gizi lebih yang merupakan masalah gizi di negara maju mulai terlihat juga di negara-negara berkembang. Ketidakseimbangan gizi dapat disebabkan tidak sesuainya jumlah tidur dikarenakan dihambatnya regulasi nafsu makan dan perubahan produksi hormon. Beberapa nutrisi yang dikaitkan memengaruhi tidur ialah makronutrien dan mikronutrien seperti vitamin B, kalsium, magnesium, dan zat besi. Penelitian ini bertujuan untuk melihat hubungan antara status gizi dan gangguan tidur. Jenis penelitian survei analitik observasional dengan desain potong lintang yang dilakukan di Sekolah Dasar di Kecamatan Tikala Manado menggunakan purposive sampling. Dilakukan pengukuran berat badan dan tinggi badan untuk mengetahui status gizi dan pengisian kuesioner SDSC oleh orang tua untuk mengetahui status gangguan tidur. Dari $249(100 \%)$ responden, 1 anak $(0,4 \%)$ masuk dalam kategori gizi buruk, 44 anak $(17,7 \%)$ masuk kategori gizi kurang, 129 anak $(51,8 \%)$ masuk dalam kategori gizi normal, 34 anak (13,7\%) masuk kategori overweight, dan 41 anak (16,5\%) masuk kategori obesitas. Sebanyak 156 anak $(62,7 \%)$ mengalami gangguan tidur sedangkan 93 anak $(37,3 \%)$ tanpa gangguan tidur. Uji korelasi Pearson tidak mendapatkan hubungan bermakna antara status gizi dan gangguan tidur $(P>0,05)$. Simpulan: Tidak terdapat hubungan bermakna antara status gizi dan gangguan tidur.
\end{abstract}

Kata kunci: status gizi, gangguan tidur, kuesioner SDCS 
Status gizi didefinisikan sebagai keadaan tubuh yang merupakan akibat konsumsi makanan dan penggunaan zat-zat gizi. Status gizi dibedakan antara status gizi buruk, gizi kurang, gizi baik, gizi lebih, dan obesitas. ${ }^{1}$ Beberapa bentuk dari gizi kurang yaitu berat badan kurang (underweight), pendek (stunting), kurus (wasting), dan defisiensi mikronutrien sedangkan gizi lebih dapat berupa berat badan lebih (overweight) atau obesitas. ${ }^{2}$

Masalah gizi kurang masih tersebar luas di negara-negara berkembang, termasuk Indonesia. Pada sisi lain, masalah gizi lebih yang merupakan masalah gizi di negara maju mulai terlihat di negara-negara berkembang. $^{2}$

Prevalensi gizi kurang pada anak usia 5-12 tahun ialah 7,2\% dan gizi buruk sebanyak 4\%. Prevalensi gizi kurang paling rendah di Bali $(2,3 \%)$ dan paling tinggi di Nusa Tenggara Timur (7,8\%). Prevalensi gizi lebih didapatkan $10,8 \%$ dan obesitas sebanyak $8,8 \%$. Prevalensi gizi lebih terendah di Nusa Tenggara Timur $(8,7 \%)$ dan tertinggi di DKI Jakarta $(30,1 \%)$. Secara umum, status gizi anak di Sulawesi Utara lebih baik bila dibandingkan dengan status gizi nasional. ${ }^{3}$

Ketidakseimbangan gizi juga dapat disebabkan tidak sesuainya jumlah tidur dikarenakan dihambatnya regulasi nafsu makan dan perubahan produksi hormon. ${ }^{4}$

Anak dengan jumlah tidur $<10$ jam dan $\geq 13$ jam dalam sehari memiliki risiko tinggi mengalami gizi lebih dan obesitas dibandingkan anak yang tidur 11-12 jam. ${ }^{5}$ Di Indonesia, Sekartini dan Adi. ${ }^{6}$ mendapatkan prevalensi gangguan tidur pada anak usia di bawah 3 tahun sebesar 44,2\% . Penelitian yang dilakukan oleh Safitri et al. ${ }^{7}$ menyatakan $79,8 \%$ anak usia 3-6 tahun mengalami gangguan tidur dengan jenis gangguan tidur terbanyak ialah gangguan memulai dan mempertahankan tidur. Gangguan tidur pada anak usia 9-12 tahun dalam penelitian yang dilakukan oleh Hilmiana ${ }^{8}$ terdapat sebesar $42,20 \%$. Pada remaja usia 12-15 tahun dalam penelitian yang dilakukan oleh Haryono et al. ${ }^{9}$ didapatkan $62,9 \%$ responden mengalami gangguan tidur dan $63,6 \%$ dari total responden yang mengalami gangguan tidur tersebut merupakan gangguan transisi bangun tidur.

Mikronutrien berperan penting terhadap tidur karena efek pada sistem neurobiologik, seperti vitamin B, besi, kalsium dan magnesium. Zat-zat gizi tersebut dapat memberikan efek promotif pada tidur sedangkan asupan yang tidak adekuat dapat menyebabkan gangguan tidur. ${ }^{9}$

Penelitian ini bertujuan untuk mengetahui hubungan status gizi dan gangguan tidur pada anak sekolah dasar di Kecamatan Tikala Manado.

\section{METODE PENELITIAN}

Jenis penelitian ini ialah survei analitik observasional dengan desain potong lintang. Penelitian dilaksanakan di Kecamatan Tikala Manado pada bulan OktoberNovember 2017. Kasus dipilih berdasarkan kriteria inklusi yang telah ditentukan. Dari keseluruhan jumlah populasi, dihitung jumlah minimal untuk sampel penelitian dan dilakukan penentuan sekolah yang dijadikan tempat pengambilan sampel. Dari 42 sekolah dasar yang terdaftar di Kecamatan Tikala Manado, terdapat 6 sekolah yang dijadikan tempat pengambilan sampel.

Penilaian status gizi dilakukan dengan mengukur tinggi badan menggunakan mikrotoa dan pengukuran berat badan menggunakan timbangan. Berdasarkan tinggi badan dan berat badan dinilai status gizi sesuai dengan kurva CDC 2000 yaitu penilaian status gizi dengan berat badan berdasarkan tinggi badan (BB/TB). Penilaian status gangguan tidur menggunakan kuesioner SDSC yang diisi oleh orang tua responden. Jika didapatkan jumlah skor >39 maka responden dikatakan memiliki gangguan tidur dan jika skor $\leq 39$ maka responden dikatakan tidak memiliki gangguan tidur. Analisis statistik menggunakan uji korelasi Pearson.

\section{HASIL PENELITIAN \\ Karakteristik responden}

Jumlah responden pada penelitian ini sebanyak 249 siswa dan siswi yang telah 
memenuhi kriteria inklusi. Karakteristik responden dalam penelitian ini terdiri dari jenis kelamin, usia, status gizi dan status gangguan tidur.

Berdasarkan Tabel 1 diketahui bahwa terdapat responden dengan status gizi buruk sebanyak 1 anak $(0,4 \%)$, responden dengan status gizi kurang sebanyak 44 anak $(17,7 \%)$, responden dengan status gizi normal sebanyak 129 anak (51,8\%), responden dengan status gizi lebih/ overweight sebanyak 34 anak $(13,7 \%)$, dan responden dengan status gizi obesitas sebanyak 41 anak $(16,5 \%)$.

Terdapat $111(44,6 \%)$ responden berjenis kelamin laki-laki dan sebanyak 138 $(55,4 \%)$ responden dengan jenis kelamin perempuan. Responden dengan usia 6 tahun terdiri dari 13 anak $(5,2 \%)$, usia 7 tahun sebanyak 41 anak $(16,5 \%)$, usia 8 tahun sebanyak 55 anak $(22,1 \%)$, usia 9 tahun sebanyak 71 anak $(28,5 \%)$, dan responden dengan usia 10 tahun sebanyak 69 anak $(27,7 \%)$.

Responden yang mengalami gangguan tidur lebih banyak dibandingkan dengan yang tidak mengalami gangguan tidur. Resonden yang mengalami gangguan tidur sebanyak 156 anak $(62,7 \%)$ dan yang tidak mengalami gangguan tidur sebanyak 93 anak (37,3\%). Responden dengan jenis kelamin laki-laki sebanyak 71 anak $(28,5 \%)$ mengalami gangguan tidur dan 40 anak $(16,1 \%)$ tidak mengalami gangguan tidur. Responden dengan jenis kelamin perempuan mengalami gangguan tidur sebanyak 85 anak $(34,1 \%)$ dan tidak mengalami gangguan tidur sebanyak 93 anak $(37,4 \%)$.

Responden dengan status gizi buruk dan mengalami gangguan tidur sebanyak 1 anak $(0,4 \%)$, responden dengan status gizi kurang dan mengalami gangguan tidur sebanyak 24 anak $(9,6 \%)$, dan tidak mengalami gangguan tidur sebanyak 20 anak (8\%). Responden dengan status gizi normal mengalami gangguan tidur sebanyak 78 anak $(31,3 \%)$ dan yang tidak mengalami gangguan tidur sebanyak 51 anak $(20,5 \%)$. Responden dengan status gizi overweight dan mengalami gangguan tidur sebanyak 26 anak $(10,4 \%)$ dan tidak mengalami gangguan tidur sebanyak 8 anak $(3,2 \%)$. Responden dengan status gizi obesitas dan mengalami gangguan tidur sebanyak 27 anak $(10,8 \%)$ dan tidak mengalami gangguan tidur sebanyak 14 anak $(5,6 \%)$.

Tabel 1. Karakteristik responden penelitian

\begin{tabular}{|c|c|c|c|c|c|c|}
\hline \multirow{3}{*}{ Karakteristik } & \multicolumn{6}{|c|}{ Status gangguan tidur } \\
\hline & \multicolumn{2}{|c|}{ Ya } & \multicolumn{2}{|c|}{ Tidak } & \multicolumn{2}{|c|}{ Total } \\
\hline & $\mathrm{n}$ & $\%$ & $\mathrm{n}$ & $\%$ & $\mathrm{n}$ & $\%$ \\
\hline \multicolumn{7}{|l|}{ Jenis kelamin } \\
\hline Laki-laki & 71 & 28,5 & 40 & 16,1 & 111 & 44,6 \\
\hline Perempuan & 85 & 34,1 & 53 & 21,3 & 138 & 55,4 \\
\hline \multicolumn{7}{|l|}{ Usia } \\
\hline 6 tahun & 7 & 2,8 & 6 & 2,4 & 13 & 5,2 \\
\hline 7 tahun & 27 & 10,9 & 14 & 5,6 & 41 & 16,5 \\
\hline 8 tahun & 33 & 13,3 & 22 & 8,8 & 55 & 22,1 \\
\hline 9 tahun & 41 & 16,5 & 30 & 12,0 & 71 & 28,5 \\
\hline 10 tahun & 48 & 19,3 & 21 & 8,4 & 69 & 27,7 \\
\hline \multicolumn{7}{|l|}{ Status gizi } \\
\hline Buruk & 1 & 0,4 & 0 & 0 & 1 & 0,4 \\
\hline Kurang & 24 & 9,6 & 20 & 8 & 44 & 17,7 \\
\hline Normal & 78 & 31,3 & 51 & 20,5 & 129 & 51,8 \\
\hline Overweight & 26 & 10,4 & 8 & 3,2 & 34 & 13,7 \\
\hline Obesitas & 27 & 10,8 & 14 & 5,6 & 41 & 16,5 \\
\hline
\end{tabular}

Hubungan status gizi dan skor gangguan tidur pada anak sekolah dasar di
Kecamatan Tikala diuji analisis dengan korelasi Pearson dan mendapatkan nilai $P=$ 
0,165 $(P>0,05)$, sehingga dinyatakan tidak terdapat hubungan bermakna antara status gizi dan gangguan tidur pada anak sekolah dasar di Kecamatan Tikala. Secara grafik hubungan kedua variabel dapat dilihat pada Gambar 1.

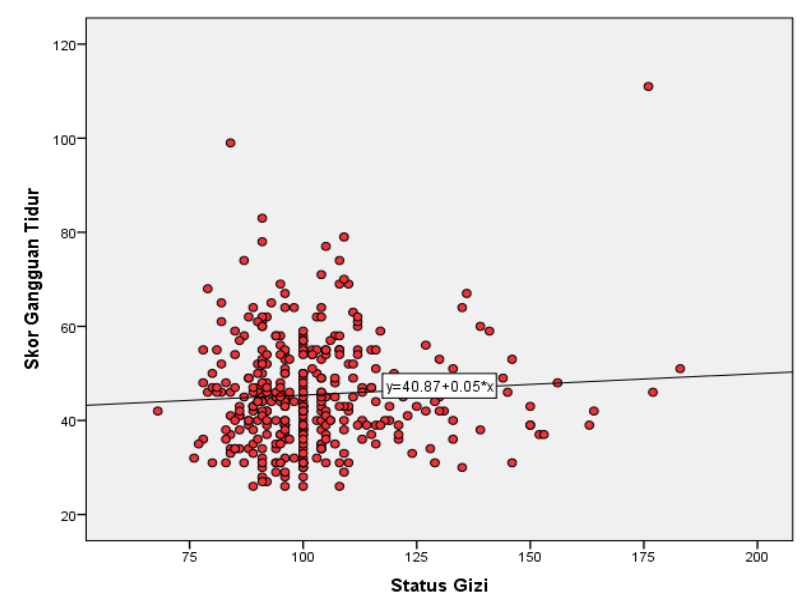

Gambar 1. Diagram pencar hubungan status gizi dan gangguan tidur

\section{BAHASAN}

\section{Karakteristik status gizi}

Berdasarkan Tabel 1 didapatkan responden dengan status gizi buruk sebanyak $0,4 \%$, status gizi kurang $17,7 \%$, status gizi normal sebanyak $51,8 \%$, status gizi lebih/overweight sebanyak 13,7\%, dan responden dengan status gizi obesitas sebanyak 16,5\%. Dari penelitian juga diketahui bahwa masih terdapat status gizi buruk.

Berdasarkan usia responden dimulai dari 6-10 tahun, diambil jumlah paling mendominasi setiap kategori. Responden yang masuk kategori status gizi buruk di temukan pada usia 8 tahun sebanyak 1 orang. Responden dengan status gizi kurang sebanyak 18 orang pada usia 10 tahun. Responden dengan status gizi normal sebanyak 36 orang pada usia 9 tahun. Pada masing-masing usia 9 dan 10 tahun di temukan responden dengan status gizi overweight sebanyak 11 orang sedangkan responden dengan status gizi obesitas ditemukan 17 orang pada usia 9 tahun.

Berdasarkan karakteristik jenis kelamin terhadap status gizi responden (Tabel
1) didapatkan lebih banyak responden dengan status gizi normal. Terdapat 25,3\% responden dengan jenis kelamin laki-laki memiliki status gizi normal dan 26,5\% responden dengan jenis kelamin perempuan memiliki status gizi normal. Pada anak sekolah dasar Kecamatan Tikala Manado ditemukan lebih banyak anak dengan status gizi normal dibandingkan yang memiliki gangguan gizi.

\section{Karakteristik gangguan tidur}

Responden dengan gangguan tidur sebanyak $62,7 \%$ dan yang tidak memiliki gangguan tidur sebanyak 37,3\%. Dari keseluruhan responden, jenis kelamin dengan gangguan tidur terbanyak ialah perempuan yaitu $34,1 \%$. Pada responden dengan status gizi buruk semuanya terdapat gangguan tidur. Pada status gizi kurang, persentase responden dengan gangguan tidur lebih tinggi $(9,6 \%)$ dibanding yang tidak memiliki gangguan tidur (8\%). Persentase responden dengan status gizi normal yang memiliki gangguan tidur $(31,3 \%)$ lebih tinggi dibanding yang tidak memiliki gangguan tidur $(20,5 \%)$. Pada responden dengan status gizi overweight, persentasi responden yang memiliki gangguan tidur $(10,4 \%)$ lebih tinggi dibanding yang tidak memiliki gangguan tidur $(3,2 \%)$. Pada responden obes, persentase yang memiliki gangguan tidur $(10,8 \%)$ lebih tinggi dibandingkan dengan responden yang tidak memiliki gangguan tidur $(5,6 \%)$. Berdasarkan bahasan ini ditemukan bahwa dalam setiap kategori status gizi persentase responden dengan gangguan tidur lebih tinggi dibandingkan dengan yang tidak memiliki gangguan tidur.

Faktor yang dapat memengaruhi tidur pada anak ialah keadaan anak yang ketakutan, suara bising, kecemasan karena merasa terpisah dengan orangtua, dan jika anak dalam keadaan sakit dapat menjadi faktor yang mengganggu tidur anak. Berdasarkan penelitian yang dilakukan oleh Istiqomah dan Lisiswanti, ${ }^{10}$ eksposur layar monitor $\geq 2$ jam per hari dapat menyebabkan gangguan tidur.

Prevalensi anak laki-laki yang menga- 
lami gangguan tidur 2-5\% lebih sering dibandingkan anak perempuan, namun pada penelitian ini ditemukan persentase perempuan yang mengalami gangguan tidur lebih tinggi dibandingkan laki-laki. Hasil penelitian ini juga berbeda dengan penelitian yang dilakukan oleh Marfuah ${ }^{11}$ di Jogyakarta, yang menyimpulkan bahwa gangguan tidur lebih banyak ditemukan pada anak laki-laki.

Setiap kategori status gizi memiliki persentase responden yang memiliki gangguan tidur lebih tinggi dibandingkan dengan responden yang tidak memiliki gangguan tidur.

Hubungan status gizi dan gangguan tidur diuji statistik dengan uji bivariat yaitu menggunakan koreasi Pearson dan didapatkan nilai $P=0,165(P>0,05)$, yaitu tidak ditemukannya hubungan bermakna antara status gizi dan gangguan tidur. Pada penelitian sebelumnya disebutkan bahwa defisiensi vitamin dan mineral seperti vitamin B6 dapat menyebabkan stres psikologis dan gangguan tidur; vitamin B12 dapat memperbaiki gejala gangguan siklus tidur-bangun; defisiensi zat besi diduga penyebab restlegs syndrome yaitu gangguan yang ditandai dengan sensasi yang tidak normal pada kaki sehingga dapat menyebabkan kesulitan memulai tidur. ${ }^{12}$ Pada penelitian ini tidak dilakukan pengukuran terhadap kadar zat tersebut, melainkan hanya dilakukan pengukuran terhadap status gizi responden penelitian.

Hasil penelitian yang selaras juga dilaporkan Cheng dan Sekartini ${ }^{13}$ yaitu tidak ditemukan hubungan bermakna antara status gizi dan gangguan tidur pada anak usia 5-7 tahun di Kampung Melayu, Jakarta Timur.

Pada hasil penelitian yang dilakukan oleh Fasyah dan Hidayah ${ }^{14}$ di Desa Padangasri Kecamatan Jatirejo, Kabupaten Mojokerto dilaporkan bahwa terdapat hubungan bermakna antara pemenuhan nutrisi dan gangguan tidur yang terjadi pada bayi usia 6-9 bulan. Bayi yang pemenuhan nutrisinya kurang mengalami gangguan tidur yang lebih banyak daripada bayi yang pemenuhan nutrisi lebih. ${ }^{12}$
Berdasarkan hasil pengamatan peneliti, status ekonomi masyarakat di daerah penelitian mayoritas menengah ke bawah, dan orang tua responden banyak yang bekerja sebagai buruh dan pembantu rumah tangga. Hal ini dapat berdampak kurangnya perhatian orang tua terhadap waktu tidur anak yang tidak teratur. Oleh karena itu, untuk memastikan apakah terdapat hubungan antara status gizi dan gangguan tidur pada anak perlu dilakukan penelitian lebih lanjut dengan metode pengambilan sampel yang berbeda dan memperhatikan faktorfaktor penyebab gangguan tidur.

\section{SIMPULAN}

Dari hasil penelitian dapat disimpulkan bahwa tidak terdapat hubungan bermakna antara status gizi dan gangguan tidur pada anak Sekolah Dasar di Kecamatan Tikala Manado.

\section{SARAN}

Disarankan untuk melakukan penelitian lanjut untuk menelusuri faktor penyebab gangguan tidur.

Sebaiknya dilakukan pemberian edukasi mengenai pentingnya tidur bagi anak.

\section{DAFTAR PUSTAKA}

1. Almatsier S. Prinsip Dasar Ilmu Gizi. Jakarta: Gramedia Pustaka Utama, 2004.

2. Kliegman RM, Stanton BF, St Geme JW, Schor NF. Nelson Textbook of Pediatrics (20th ed). Behrman RE, editor. Philadelphia: Elsevier, 2016.

3. Badan Penelitian dan Pengembangan Kesehatan. Riset Kesehatan Dasar. Jakarta: Kementerian Kesehatan RI; 2013

4. Sherwood Lauralee. Susunan saraf pusat. In: Yesdelita N, editor. Fisiologi Manusia dari Sel ke Sistem (6th ed). Jakarta: EGC, 2011; p. 182.

5. Wang F, Liu H, Wan Y, Li J, Chen Y, Zheng J, et al. Sleep duration and overweight/obesity in preschool-aged children: a prospective study of up to 48,922 children of the Jiaxing birth cohort. Sleep. 2016;39(11):2013-9.

6. Sekartini R, Adi NP. Dept Ilmu Kedokteran Komunitas FKUI-RSCM. Gangguan tidur pada anak usia bawah 3 tahun di 
lima kota di Indonesia. Sari Pediatri. 2006;7:188-93

7. Zahara DS. Hubungan antara gangguan tidur dengan pertumbuhan pada anak usia 36 tahun di kota Semarang [Karya Tulis Ilmiah]. Semarang: Fakultas Kedokteran Universitas Diponegoro; 2013.

8. Hilmiana P. Studi deskriptif gangguan tidur pada anak usia 9-12 tahun di SD Negeri Pisangan 1 Ciputat. 2015

9. Haryono A, Rindiarti A, Arianti A, Pratiwi A, Ushuluddin A, Setiawati A, et al, Dept Ilmu Kesehatan Anak FKUIRSCM. Prevalensi gangguan tidur pada remaja usia 12-15 tahun di sekolah lanjutan tingkat pertama. Sari Pediatri. 2009;11: 149-54.

10. Istiqomah SN, Lisiswanti R. Dampak eksposur layar monitor terhadap gangguan tidur dan tingkat obesitas pada anak-anak. Majority, 29176(2):73-8.

11. Marfuah D. Kualitas tidur hubungannya dengan obesitas pada anak sekolah dasar di Yogyakarta, Profesi. 2014;12:46-52.

12. Sarrafi-Zadeh S, Dhawadkar S, Singh RB, Meester FD, Wilczynska A, Wilson DW, et al. Nutritional modulators of sleep disorders. The Open Nutraceoticals Journal 2012;5:1-14.

13. Cheng W, Sekartini R. Hubungan status gizi, asupan besi dan magnesium dengan gangguan tidur pada anak usia 5-7 tahun di Kampung Melayu, Jakarta Timur Tahun 2012. Ejournal Kedokteran Indonesia, Agustus 2014, Jakarta: FKUI

14. Fasyah RC, Hidayah N. Hubungan pemenuhan nutrisi pada bayi dengan kualitas tidur di BPS Ny. Siti Naimah Amd. Keb di desa Padangasri Kecamatan Jatirejo, Kabupaten Mojokerto. Hospital Majapahit. 2017;5(1):15-31. 